\title{
SOCIAL AND PSYCHOLOGICAL FEATURES OF DISABLED STUDENTS' INTEGRATION IN THE INCLUSIVE GROUPS
}

\author{
Kurbanova A.T ${ }^{1}$ and Artishcheva L. $\mathrm{V}^{2}$ \\ ${ }^{1,2}$ Kazan federal university/ Institute of Psychology and Education
}

\begin{abstract}
The aim of the research: Training in the inclusive higher school environment supposes joint training of higher school students with functional limitations, with other students in the integrated group. Social and psychological aspects of this phenomenon are studied insufficiently. In particular, the study of the acceptance degree of a student with disabilities in an inclusive group needs special attention. The indicators of sociometric status of a student with disabilities can help determine how well they are included in the team, how well they are accepted in the group. They also help assess the effectiveness of integration into the society at large. We should also note that the success of the actions of young people with disabilities will largely depend on their willingness to be active, able to initiate their own development, and act as a source and the cause of their own behavior, to overcome the negative impact of a situation of uncertainty, i.e. on the ability to self-determination.
\end{abstract}

Methods: The sociometric test for the diagnostics of emotional links between members of the inclusive group, tests, studying personal self-actualization, method of studying the training motivation in higher school.

Main results: we identified specificity of emotional interaction between the members of an inclusive group. The features of the personal potential of students with disabilities in comparison with healthy students were shown. Differences in educational motivation are presented.

Conclusions: The position of a student with disabilities in the inclusive group has sociometric status of the one "who joined" or "isolate". That is the level of unity of inclusive groups is insufficient. The level of self-actualization of students in the inclusive groups depends on various conditions within the group and on the specific health problems. At the same time students with disabilities devote a driving position to motivation of acquiring knowledge and mastering profession in the hierarchy of motives.

Keywords: Inclusive education, inclusive groups, self-actualization, motivation, sociometric status.

\section{INTRODUCTION}

Education of students with disabilities is the subject of an old and extensive discussion in a professional community of many countries $[20,21,35,51,53$, 56]. In Russia, inclusive education development dates back to 2012 when the country joined the UNO Convention on the Rights of Persons with Disabilities [11]. On June 1, 2012 the Decree of the Russian Federation on the rights of persons with limited health opportunities to receive inclusive education of

Corresponding author email: ladylira2013@yandex.ru all levels came into effect [8].

The practice of inclusive education as a mass phenomenon is only at its initial stage of development at higher school of Russia. Mechanisms of educational process adaptation to individual educational needs of each student having various forms of disability are being created; tasks of all experts participating in creation of inclusive practice of higher education are being specified [1-3, 4, 5, 26, 43, 44, 45, 54]. Experience of countries with a long history of training students with limited health 
possibilities (LHP) shows: teachers of higher education institutions play a leading role in disabled students' inclusion both in educational process and extra curricula activities [7, 15, 25, 39]. The pedagogical community of Russia widely discusses issues of experts' training improvement in the field of teaching children and adults with LHP [18, 19, 32, $50]$.

A versatile study of LHP students' psychological wellbeing in the context of inclusive training, opportunities for self-actualization in learning and social contacts make an important component for creation of a new practice in higher education institutions of Russia. The issue of self-actualization proposed by American psychologists-humanists [28] is widely researched in higher education of Russia. The theory of personality development considers selfactualization as person's aspiration to continuous individual development, effective realization of potentials in the course of activity aimed to achieve public recognition [41]. Models of conditions to develop students' self-actualization are suggested; the role of higher school teachers in this process is being studied [6, 40]. Key tendencies of modern Russian students' self-actualization are being revealed in different spheres of their vocational training [24, 36].

Adaptation educational programs for LHP students include disciplines promoting self-awareness and self- actualization [26, 27].

At the same time empirical researches of LHP students' self- actualization are quite limited [38, 55].

Inclusive practice imposes high demands for all participants of an educational process. LHP students are required to mobilize intellectually and psychologically. In this regard, the problem of LHP students' motivation to study at a higher education institution turns to be extremely important.

Educational motivation is defined as a specific type of motivation included in learning activity [14, 33, 34]. Pedagogical conditions and means to increase motivation of LHP students are discussed within the frames of inclusive education research; however the number of psychological researches of disabled students' learning motivation at a higher education institution is not enough $[37,52]$.
Some empirical researches compare learning motivation of LHP students and students without disability. There are data that disabled people have higher motivation for learning, they are more conscientious when doing their tasks. Motives of prestige and social motives are significantly higher in the structure of educational motivation of students with hearing disorder than students without impairment. Motives of creative self-realization and communicative motives of students with hearing disorder take the first place in the hierarchy of educational activity motives; "healthy" students consider professional motives as more important [23, 47].

Relationships with teachers, heads and personnel of an educational organization determine psychological availability: general positive thinking and friendly atmosphere for LHP students. Social and psychological situation in group where there are students with special educational needs is its major component [16, 17].

Desire to take a certain place in a group is an important feature of student's age; the sociometric status is a recognized indicator to assess the quality of group relations in general, and situations for its each member. The following is widely studied at a high school: the degree of internal satisfaction of popular students and students who are not accepted by the group; a psychological portrait, psychological structure of proneness to conflicts, academic success of students with various status in the group; personal determinants of low sociometric status; the ratio of cooperation and competition in interpersonal relations in a student group [9, 10, 12, 22, 29, 42, 49].

At the same time, researches of sociometric characteristics of LHP persons in a student group are sporadic; results are often contradictory. There are some data about the way students with visible forms of disability are accepted by other students, and that disabled people have the status of rejected, and they are more often isolated. Comparative researches show that a lower sociometric status of students with special educational needs is characteristic for higher education institutions that are not specialized on training of LHP people and those located in towns [13, 30, 46, 48]. In general, studying of social and psychological features of disabled students' 
integration into educational space of higher school in Russia is obviously insufficient.

The aim of the research is to study features of social and psychological integration of disabled students in an inclusive student's group through indicators of self-actualization, educational motivation and sociometric status.

\section{MATERIALS AND METHODS}

6 academic groups from higher education institutions of Kazan participated in the research; all in all there were 59 students, 11 students are LHP students. The following parameters were studied: features of LHP students' interpersonal relationships situations (Moreno's method of sociometry); the level of students' in norm and LHP students' selfactualization within inclusive education (Shostr, Alyoshina, Zagik, Gozman \& Kroz). Also, Ilyina's technique of studying learning motivation at a higher education institution was applied to identify the prevailing type of learning motivation at a higher education institution.

The method of sociometry included 4 groups of questions: 1. desire/unwillingness to share the same desk; 2. desire/unwillingness to ask questions and problems; 3 . desire / unwillingness to communicate at an education institution; 4. desire/unwillingness to communicate in social networks. The following sociometric indicators were specified: expansiveness, positive and negative; integration, positive and negative; unity. The level of self-actualization was measured according to two basic and 12 additional scales, independent from each other: valuable orientation, flexibility of behavior, sensitivity to oneself, spontaneity, self-esteem, self-acceptance, ideas of human nature, synergy, acceptance of aggression, sociability, cognitive requirements, creativity. The level of motivation was determined according to three scales: "Acquisition of knowledge" (aspiration to obtain knowledge, inquisitiveness); "Mastering a profession" (aspiration to master professional knowledge and create professionally significant qualities); "Getting a Degree" (wish to get a Degree upon formal assimilation of knowledge, wish to find alternative ways to pass examinations and tests).

All obtained results were analyzed with Statistika 6 program application.

\section{RESULTS}

Fig. 1 shows the analysis of sociometric data reflecting expansion, integration and unity in inclusive groups in general.

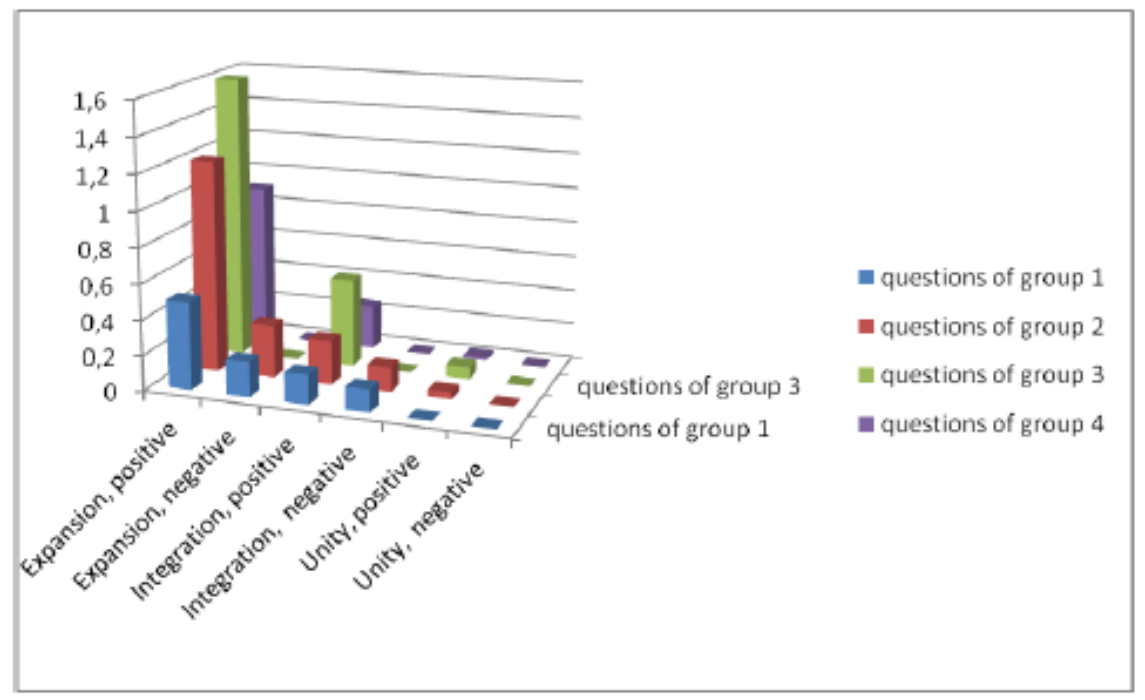

Figure 1. Indicators of expansiveness, integration and unity in inclusive student's groups

The maximum positive expansiveness and the absence of the negative one are revealed when students communicate informally at an institute and in social networks (groups of questions 3 and 4). 
Students of inclusive groups are more selective in educational (group of questions 2) and especially close communication (the 1st group of questions).

The ratio of integration indicators is similar to expansion indicators, but has quite a smaller value. That is, inclusive groups of students are more integrated at informal communication and in social networks. At the same time, total absence of unity which characterizes the sphere of the closest communication and contacts in social networks (group of questions 1 and 4) is specified.

Let us consider individual sociometric indices. It was revealed that LHP students have zero values of indices of sociometric status (both positive and negative) in group of questions 1,2 and 4. No one of group members mentions who they want to sit at the desk next to, but does not speak about refusal to sit with them either. Groups do not apply with questions and difficulties arising in their study, but at the same time they do not refuse to address in such occasions; they do not communicate in social networks and do not refuse to see LHP students among their friends. That is, other group members do not choose, do not show activity, initiative in relation to HLP students and do not reject them.

Let us further analyze the degree of students' selfactualization in inclusive groups (Fig. 2).

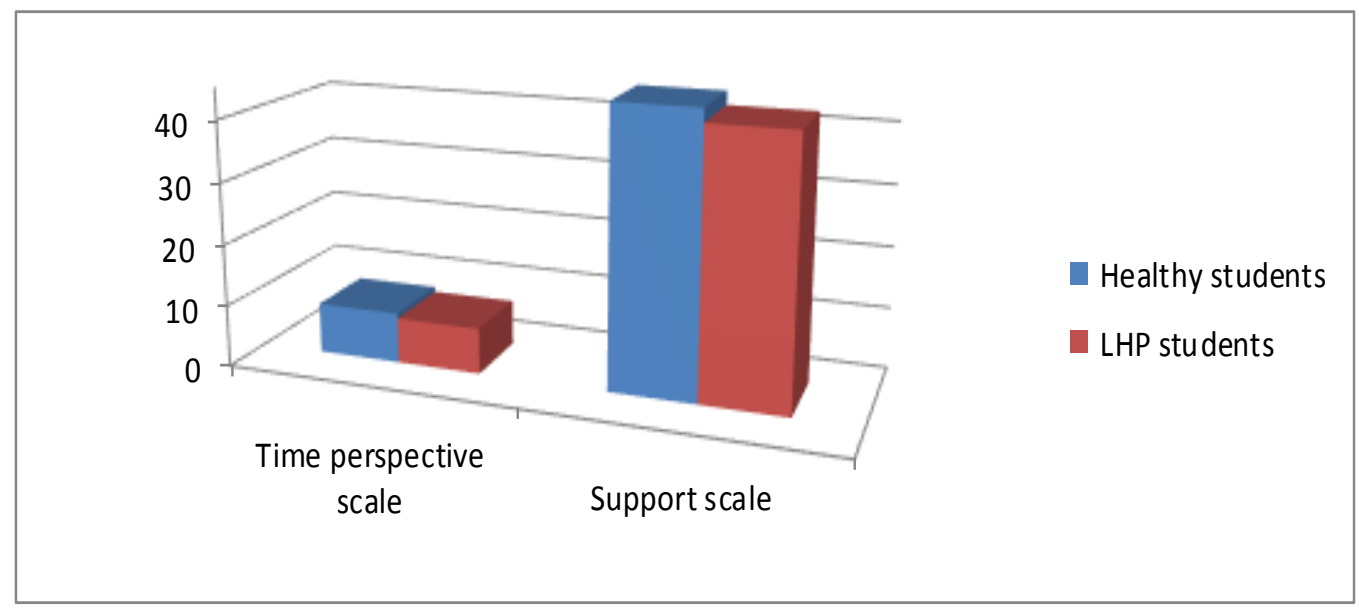

Figure 2. Average values of main scales of "Self-actualization Test" technique

According to the scale time perspective LHP students (7.4) and "healthy" students have close values within average limits (maximum value according to this scale is 17 scores). The obtained result demonstrates that both "healthy" students and LHP students are capable to take their life on the whole, inseparable from past, future and present. That very life and world perception testifies to a quite high level of personality self-actualization. Let us note that the more vivid difference of students' answers was revealed despite high values on the scale support which vary within above average in relation to maximum possible (92 scores). "Healthy" students
$(50,1)$ has higher indicator value than LHP students $(42,8)$. It points out that "healthy" students are relatively independent from outside impacts in their actions and strive to follow their principles and sets. LHP students are characterized by less independence that means a high degree of dependence and conformity, and shows LHP students' dependence on external circumstances. Such external locus of control specifies the fact that LHP students' personal choice is influenced by external circumstances.

Fig. 3 presents the ratios that students of various types of learning motivation have at a higher education institution (Ilyina's technique). 


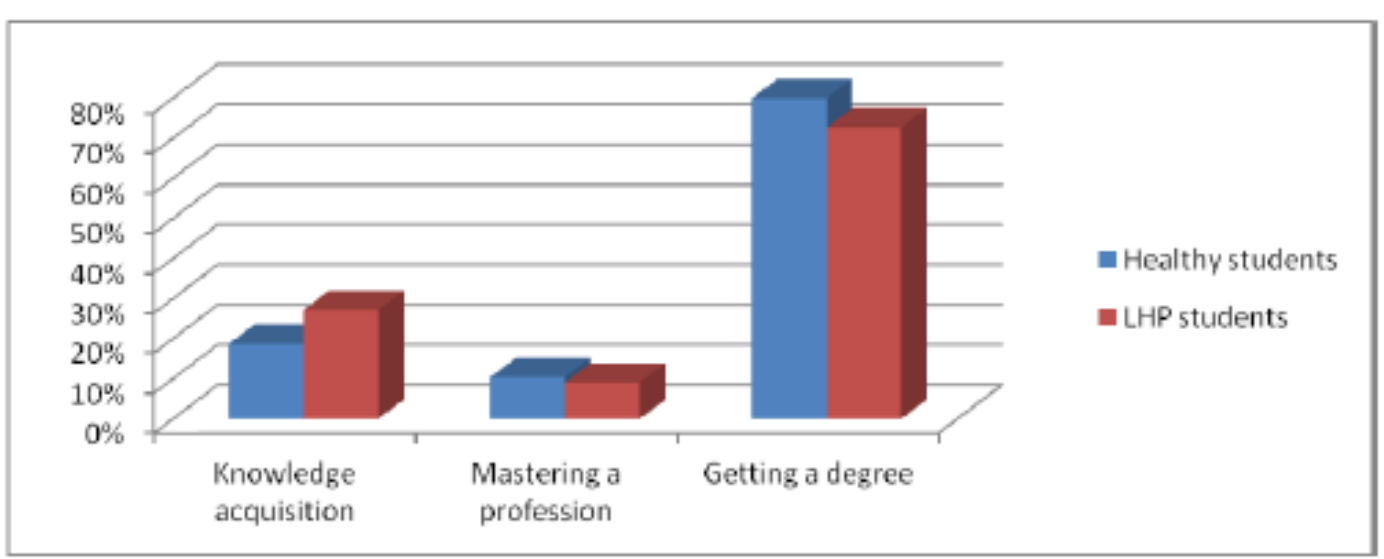

Figure 3. A ratio of various types of learning motivation at a higher education institution (Ilyina's technique)

The leading motivation of the majority of "healthy" students $(81.2 \%)$ and LHP students $(72.7 \%)$ is getting a degree, though LHP students consider this socializing motive as less significant. The motivation mastering a profession is less expressed; it mostly concerns LHP students $(9.1 \%$ in comparison with $10.4 \%$ of "healthy" students). At the same time LHP students' aspiration to obtain knowledge is higher than in the sample of "healthy" students $(27.2 \%$ in comparison with $18.8 \%$ of healthy students). In general, LHP students and "healthy" students are alike when it concerns the hierarchy of learning motives at a higher education institution. In both cases the motivation getting a degree is prevailing; it indicates that young people do not consider higher education as a stage of their career and vocational growth but as a final socially substantiated goal. LHP students' lower motivation mastering a profession is caused by less freedom when they choose a higher education institution, specialized training and opportunities of further professional growth. At present not all higher education institutions, not all training directions are available for LHP students; besides not all employers are ready to provide such people with workplaces. Despite this fact, LHP students' motivation obtaining knowledge is higher; they are more knowledge oriented. Thus, LHP students' motivation of studying at a higher education institution is supposed to be more auspicious in comparison with "healthy" students.

Conclusion. The research results showed that inclusive groups of students are more integrated at informal communication and in social networks. The sociometric status of LHP students is the following: they take the position of an adjoined peripheral group member more often, they do not receive negative choices, but at the same time they get a positive choice only in the sphere of communication in social networks. Let us also note that insufficient integration into a group characterizes not only LHP students but "healthy" students as well.

The research of students' self-actualization in inclusive groups showed that on the scale time perspective LHP students and "healthy" have close indicators; their perception of life is holistic, they live now and here; that testifies to a rather high level of personality self- actualization. It was revealed that LHP students are less independent.

The research of learning motivation showed that motivation getting a degree is prevailing both for most "healthy" students and LHP students. LHP students are focused on knowledge acquisition, and "healthy" students are oriented to mastering a profession. Therefore, the system of LHP students' learning motivation at a higher education institution can be considered as more auspicious in comparison with "healthy" students' motivation.

\section{REFERENCES}

Ahmetzyanova, A.I. (2015). Fear and Anxiety in the Children Suffering from Infantile Cerebral Palsy and Raised in Families with Various Parental Subsystems. Asian Social Science. 11, (7), 356361.doi:10.5539/ass.v11n7p356

Ahmetzyanova, A.I. (2015). Anticipation and Prediction Interrelation Neuropsychological Mechanisms at Youthful Age. The Social Sciences, 10, 399401.DOI:10.3923/sscience.2015.399.401 
Akhmetzyanova, A.I. (2014). The Development of SelfCare Skills of Children with Severe Mental Retardation in the Context of Lekoteka. World Applied Sciences Journal. 29 (6), 724-727

Akhmetzyanova A.I., Artemyeva T.V., Nigmatullina I.A., Kurbanova A.T., \& Tvardovskaya A.A. (2015). The Model of Inclusive Educational Space of Federal University The Social Sciences. 10 (7), 2089-093

Berus E. I., \& Dulepova N. V. (2013). The model of inclusive education at Novosibirsk State University Proceedings of the International educational forum: International dialogue: inclusion through whole life. Moskow, M. Vuzovskaya kniga

Bolshakova, O.N. (2011). The development of selfactualization in students. Scientific notes of University named after P. F. Lesgaft 7 (77), 27-31

Brandon, T., \& Charlton, J. (2011). The lessons learned from developing an inclusive learning and teaching community of practice. International Journal of Inclusive Education. 15 (1), 165 - 178

Decree of the President of the Russian Federation (1 June, 2012 Decree) On National strategy of actions in interests of children for $2012-2017$ (N 761)

Dobina, N.I. (2011). Psychological structure of a conflictness of students with different sociometric status. $\mathrm{PhD}$ thesis Candidate of Pedagogical Sciences.

Drozdov, I. I., \& Kapitanova, E. V. Drozdova (2014). Social and psychological factors of the personality in academic group. Engineering journal of Don, 4. Retrieved from http://ivdon.ru/ru/magazine/archive/n4y2014/2698

Federal law (2012). The ratification of the UN Convention on the Rights of Persons with Disabilities Retrieved from http://www.komitet8.km.duma.gov.ru/site.xp/051057051.ht $\mathrm{ml}$

Fokina, I. V., \& Sokolovskaya, O. K. (2015). Psychological portrait of a student with low socio-metric status in the academic group. Prospects of Science and Education. 3 (15), 126-131

Gayvoronskaya, D. L., \& Yandanova, T. I. Gayvoronsky Diagnostics of interpersonal relations in the student group of persons with disabilities. Regional scientific-practical conference: Mental and physical health: medical, social, psychological and psycho-pedagogical aspects. Irkutsk: Irkutsk State University. Irkutsk: Irkutsk State Univercity

Gordeeva, T.O. (2013). Motivation of educational activity of pupils and students: structure, mechanisms, development conditions. $\mathrm{PhD}$ thesis Candidate of Psychology. 46. Retrieved from http://psycdigest.ru/articles/pdf/dissertation/Gordeeva_TO_ ref.pdf

Gurkina, O.A., \& Novikova, E.M. (2014). Foreign experience of social and educational inclusion of people with disabilities on the example of higher education study. Modern foreign psychology. 3(1), 6-15. Retrieved from http://psyjournals.ru/jmfp/2014/n1/69038.shtml

Hans, S. (2011). Reinders. Journal of Religion, Disability \& Health - The Power of Inclusion and Friendship. Retrieved from

http://www.tandfonline.com/doi/full/10.1080/15228967.20 11.619341\#.U7Elpfl_uc0
Hill, D., \& Brown, D. (2013). Supporting inclusion of at risk students in secondary school through positive behaviour support. International Journal of Inclusive $\begin{array}{llll}\text { Education. } & 17 & \text { (8), } & \text { 868-881 }\end{array}$ http://cyberleninka.ru/article/n/psihologicheskayagotovnost-k-buduschey-professionalnoy-deyatelnostistudentov-s-narusheniyami-sluha-na-primere-mgtu-im-n-ebaumana

Kalimullin, A.M. (2014). Improvement of Teachers' Qualification at Kazan Federal University. World Applied Sciences Journal. 30 (4), 447-450

Kantor, V.Z.(2013). Psychological and pedagogical principles of teaching students with disabilities in higher education. In B. B. Asmontas (Ed.). Social rehabilitation of persons with disabilities as an area of training: problems, experience, prospects (pp. 319-333). Moscow, MSUPE

Kim, J. (2011). Influence of teacher preparation programmes on preservice teachers' attitudes toward inclusion. International Journal of Inclusive Education. 15 (3), 355-377

Korepanova I. A. (2012). Notes about inclusive landscape of Germany. Dubna Psychological Journal, 4, 13-20. Retrieved

from http://www.psyanima.ru/journal/2012/4/2012n4a2/2012n4a 2.pdf

Korobitsin, V. D. (2013). Personal determinants of students with low sociometric status. Pedagogical education in Russia. $5 . \quad$ Retrieved from http://cyberleninka.ru/article/n/lichnostnye-determinantynizkogo-sotsiometricheskogo-statusa-studentov

Kozhemyakina, E. A., \& Antonov, A. A. Kozhemyakina (2015). Psychological readiness for future professional activity of students with hearing impairments (on the example of the MSTU named after N. E. Bauman). Bulletin of Medical Internet Conferences. 5 (5). Retrieved from http://cyberleninka.ru/article/n/psihologicheskayagotovnost-k-buduschey-professionalnoy-deyatelnostistudentov-s-narusheniyami-sluha-na-primere-mgtu-im-n-ebaumana

Lopatin, E. A. (2008). The study of self-actualization of 1719-year-old students. Izvestia of Russian State Pedagogical University named after A. I. Herzen. 65

Malofeev N. N. (2003). Western Europe: the evolution of attitude of society and state to persons with developmental disabilities. Moscow, M. Ekzamen

Marytinova E. A. \& Romanenkova D.F. (2013). The main approaches to the development of the Federal state educational standards of higher education subject to the conditions of inclusive education of disabled persons. Materials of II International scientific and practical conference: Inclusive education: practice, research, methodology. Moscow: MSUPE

Martynova E. A. \& Romanenkova D.F. (2010). The model of the center for the education of disabled people in Chelyabinsk State University on the basis of the system of integrated education. Retrieved from http://vo.hse.ru/data/2010/12/31/1208182062/11mar.pdf

Maslow, A. (1999). Motivation and Personality (A. M. Tatlibaeva, Trans.). Sankt-Peterburg, Spb.: Evrasia 
Mikheeva, G. A. (2008). The formation of the system of interpersonal relations in students. Izvestia of RSPU named after A. I. Herzen. 67. Retrieved from http://cyberleninka.ru/article/n/formirovanie-sistemymezhlichnostnyh-otnosheniy-studentov

Murashko, V. V. Social and psychological factors of the adaptation of students with visual impairment to the learning environment at the University. $\mathrm{PhD}$ thesis (Candidate of Psychology. Sankt-Peterburg. Retrieved from http://psibook.com/research/sotsialnopsihologicheskie-faktory-adaptatsii-studentov-s narusheniyami-zreniya-k-usloviyam-obucheniya-vvuze.html

file:///C:/Users/User/Downloads/01003054862.pdf

Nazarova N. (2010). Integrated (inclusive) education: Genesis and problems of implementation Social pedagogy. $1,77-87$

Nigmatullina, I.A, \& Artemyeva, T.V. (2015). Integration of Educational and Research Activity of the Federal University Students, Studying in the Approach «Special (Speech Pathology) Education». The Social Sciences. 10 (2), 76-80

Ovchinnikov, M.V. (2008). Dynamics of learning motivation in the students of pedagogical higher education institution and its formation. $\mathrm{PhD}$ thesis Candidate of Psychology. 26

Pakulina, S.A. (2004). Adaptive abilities of students of the Pedagogical University: structure, factors and methods of developing. $\mathrm{PhD}$ thesis Candidate of Psychology. 24

Polat, F. (2011). Inclusion in education: A step towards social justice. International Journal of Educational Development. 31 (1), 50 - 58

Repina, K. G. (2011). Self-actualization of students in the Art department of Pedagogical University. Stages, barriers and mechanisms of self-actualization. A young scientist. 12 (2), 68-70. $\quad$ Retrieved from http://cyberleninka.ru/article/n/izuchenie-samoaktualizatsii17-19-letnih-studentov-vuza

Romanenkova, D. F. (2013). Features of realization of professional educational programs using e-learning, distance learning technologies in the conditions of training persons with disabilities and persons with limited possibilities of health. Modern problems of science and education. 4. Retrieved from http://scienceeducation.ru/ru/article/view?id=9841

Romanovich, N.A. (2015). The formation of readiness of persons with disabilities to professional self-determination in the process of pre-University training $(\mathrm{PhD}$ thesis Candidate of Pedagogical Sciences). Chelyabinsk

Sage Hargreaves. (2011). The Fourth Way: The inspiring future for educational change. Joint publication with Ontario Principals Council and National Staff Development Council. California

Shuchkovskaya, E.S. (2014). The role of reflexivity in students' self-actualization. Petropavlovsk-Kamchatsky: KamGU named after Vitus Bering

Smirnova, T.L. (2007). Self-actualization of the student's personality in the process of training economists. The fundamental research. 12 (1), 166-167. Retrieved from http://www.fundamental-

research.ru/ru/article/view?id=4059
Stepanov, F. G. (2015). Individually-typological peculiarities of the personality and sociometric status of students in a group: Theoretical and practical issues of modern science. Scientific works of the VII International conference of the Eurasian Scientific communities. Moscow: ESC

The Model of Inclusive Educational Space of Federal Universitetet. (2015). The Social sciencies. 10 (7), 2089$2093 . \quad$ Retrieved from http://www.medwelljournals.com/abstract/?doi=sscience. 20 15.2089 .2093

The participation of public organizations including people with disabilities in the development of inclusive education. (2012). In Turkina T. G. (Ed.). Moscow, M.: Perspectiva

Tvardovskaya, A.A. (2013). On the question of the development of inclusive education in the Republic of Tatarstan. International educational forum: International dialogue: inclusion through life. Moscow, M.: Vuzovskaya kniga

Voevodina, E. V., \& Gorina, E. E. (2011). The experience of organization of sociological researches on the adaptation of students with disabilities at non-specialized institute. Bulletin of the Association of universities for tourism and service. 2. Retrieved from http://cyberleninka.ru/article/n/ob-opyte-organizatsiisotsiologicheskih-issledovaniy-adaptirovannosti-studentovs-ogranicheniyami-zhiznedeyatelnosti-v-usloviyah

Voevodina, E. V., \& Gorina, E. E. (2013). Education as a factor of increasing the competitiveness of persons with disabilities. Bulletin of VSU. 2, 60-62

Voevodina Воеводина, Е.В., \& Горина, Е.Е.. (2013). Social portrait of people with disabilities in the students' environment as a factor of social adaptation to the University. Bulletin of the Tomsk State University. 373, 6065.

Volkov, A. A., \& Zerkalova, E. A. Volkov (2014). Empirical research on the impact of social support, social status and gender on the academic success. Modern foreign psychology. 2, 29-40

Vyakhyakuopus, E. (2013). Psychological and pedagogical principles of teaching students with disabilities in higher education. In B. B. Asmontas (Ed.). New challenges and methods of qualification improvement for specialists in social rehabilitation of persons with disabilities (pp. 301319). Moscow: MSUPE

Waldschmidt, Anne. (2011). Selbstbestimmung als behindertenpolitisches Paradigma. Politische Partizipation und Selbstvertretung. Retrieved from http://www.lvr.de/media/wwwlvrde/soziales/berdasdezernat _2/dokumente_228/hilfenauseinerhand/vortrag_lvr_koeln_ 111207.pdf

Yarskaya-Smirnova, E. R., \& Romanov, P. V. YarskayaSmirnova (2005). Accessibility of higher education for the persons with disabilities. Retrieved from http://elar.urfu.ru/bitstream/10995/780/1/UM-2005-0110.pdf

Yarskaya-Smirnova E. R., Nabirochkina E. K. (2004). Social work with disabled people. (2th Ed.). Sankt-Perburg: Piter. Retrieved from URL:http://socpolicy.ru/wpcontent/uploads/2012/02/SW_with_Disabled.pdf 
Zagumenov Y.L. (2008). The value of professional pedagogical education: the inclusive approach Abstracts of II International scientific-practical conference: Postgraduate education: achievements and current directions of development: Minsk: Academy of postgraduate education

Zalaletdinova, A. D., Minyukova, J. E., Novichenko, A. A., Fedorova, N. A., Fayzrakhmanova, A. T. (2014). The selfdetermination of students in inclusive education in the Federal University. Sides of science. 2 (2), 22-25
Zhavoronkov R. H. (2015) the technology of higher inclusive education of persons with disabilities in the United States of America. Retrieved from http://www.vashpsiholog.info/psih/20317-texnologiya-vysshegoinklyuzivnogo-obrazovaniya-invalidov-primenyaemaya-vsoedinennyx-shtatax-ameriki.html/ 